\title{
Socio-Economic Status of Youth and Involvement in Criminal Activities in Calabar Metropolis of Cross River State, Nigeria
}

\author{
${ }^{1}$ Uyang, Francis Abul, ${ }^{2}$ Festus Nkpoyen Ph.D, ${ }^{3}$ Bassey, Glory Eteng \\ Department of Sociology Faculty of Social Sciences University of Calabar P. M. B. 1115 - Nigeria \\ 'uyangabul@yahoo.com, ${ }^{1}$ sabenof@yahoo.com, ${ }^{3}$ gloryeteng@yahoo.com
}

\begin{abstract}
The study examined the relationship between socio-economic status of youth and involvement in criminal activities in Calabar Metropolis of Cross River State, Nigeria. Two null hypotheses were formulated based on the identified independent variables of poverty and unemployment. Using the survey research design, data were collected from 100 randomly selected respondents and statistically analyzed using the Pearson Product Moment Correlation analysis with a 0.05 alpha significant. Result showed a significant relationship between poverty and youth involvement in criminal activities on one hand and between unemployment and youth involvement in criminal activities on the other. We recommend among other things, that parent(s) should support their children to choose vocational skills training as it will help to reduce poverty and increase employability. Also, poverty alleviation programmes should be pro poor and getting to the right people which the programme(s) is design for, both in the rural and urban areas rather than politicians using it to enrich themselves and compensate their supporters and patronage.
\end{abstract}

Keywords: Socio-economic status of youth, criminal activities, poverty, unemployment

\section{INTRODUCTION}

Youth involvement in criminal activities in Nigeria has assumed a worrisome dimension in recent times. There has been an increase in the occurrence of acts of violence and lawlessness, including hostage taking of prominent citizens and expatriate oil workers as well as oil bunkering, arms insurgence, cultism etc especially in the Niger Delta region. Nigeria is among the developing countries of the world, and is experiencing a prevalence of rising crime waves, criminal intentions and varying degree of delinquencies. The nature of these crimes include armed robbery, murder, car theft, burglary, gambling, smuggling, human trafficking, kidnapping, drug trafficking, internet scam, advanced fee fraud (419) and other illegal activities (Eyegbeleye, 2005; Adebayo, 2013).

Nearly everywhere and around Nigeria cities, the atmosphere is inflicted with criminal menace being wrecked on law-abiding members of the Nigerian public by criminals. The highway has become a theatre for frequent robbers, car snatching and murder, while homes of the rich and the poor are targets of daily murderous campaigns by hoodlums (Ushie, 2000). There are reports of crimes committed mostly by the youths at virtually every corner of the country. Youth's involvement in criminality has become an integral part of the nation's daily life (Adebayo, 2013). Youth is an important development phase in human life and the most energetic forces of the society. Different characters, structures, goals, and temperaments have been reflected in their life due to the impact of socio-economic status (Konch \& Borbora, 2013).

Youth involvement in criminal activities in Nigeria is not a recent phenomenon. What is new, however, is the increasing phenomenon of youth restiveness, armed robbery and other social vices resulting socio-economic status of the youth (Nwagbara, 2007 cited in Ugal, Nwagbara \& Uyang, 2011). The activities of these youths who had gotten themselves involved in all manner of crime is noted to have reached an alarming proportion in contemporary time. The weapons and methods used by youth involved in criminal activities are getting more sophisticated leading to state of helplessness. Criminal activities are becoming the order of the day. This has been attributed to factors such as the widening gap between the various social classes, unemployment, poverty, rural/urban drift, peer pressure etc, (Eli, 2002).

The youths constitute a vital segment of the society in which they live. A disciplined, focused and law-abiding youth can create bright future for the nation. While a lawless, indulgent and violent youth is a great threat to a nation's peace and security (Amadu, 2007). Based on the gap existing in 
knowledge, this study attempted to highlight the socio-economic factors responsible for criminal activities among youths in Calabar metropolis of Cross River State, Nigeria.

\section{OBJECTIVES OF THE STUDY}

- To examine the relationship between poverty and youth's involvement in criminal activities in Calabar Metropolis of Cross River State.

- To determine the relationship between unemployment and youth's involvement in criminal activities in Calabar Metropolis of Cross River State.

\section{RESEARCH HYPOTHESIS}

- There is no significant relationship between poverty and youth's involvement in criminal activities.

- There is no significant relationship between unemployment and youth's involvement in criminal activities.

\section{LITERATURE REVIEW}

People are referred to as poor when their measured standard of living in terms of income or consumption is below the poverty line which is also a measure that separates the poor from the rich (Obadan, 2001). According to Chambers (1995), poverty is the lack of physical necessities and income. It is a general condition of deprivation which comprises special inferiority, isolation, physical weakness, vulnerability, powerlessness and humiliation. For Sancho (1996), poor people are those who are unable to obtain an adequate income, stable job, own property or maintain healthy condition of living.

According to Salor (2010) cited in Adebayo (2013), a 2007 UNDP survey on poverty and extreme deprivation of 108 countries ranked Nigeria at 80th position, giving it a Human Poverty index of $37.3 \%$ among the lowest for the entire continent. He maintains that for a country that earns an estimated \$2.2 million in daily petrodollar revenue, it is surprising that the figures reflect an impudent malaise that has invaded every aspect of the life of Nigerian. Poverty is a social condition that leads the youth to crime. The poor are led to crime because of their relative deprivation and acute sense of want. The poor and jobless in Nigeria take to crime as a means of sustenance. The unemployed in Nigeria experience low self esteem, deprivation, frustration and acute want. This condition of the poor and unemployed youths leads them to criminal and deviant behaviour in the society (Adebayo, 2013).

According to Bassey (2001), the unemployed and poor youths are involved in armed robbery, fraud, kidnapping and used for electoral violence. Poverty is of the reasons why youths engage themselves in criminal activities in our present society. This is because most youths with lack of financial resources fend for themselves in school. Some end up earning their living in the street through obnoxious and criminal means they deem necessary to sustain their living (Benson, 2004; James, 2001).

Joe (1979) reported from his research in Singapore that over $70 \%$ of youths who engaged in crimes like armed robbery, theft, burglary, etc were victims of unemployment. He therefore warned that crime rate is likely to increase in times of serious economic crisis. Adejumola \& Tayo-Olajubulu (2009) commented that unemployment is the major cause of social vices like armed robbery, destitution, prostitution, political thuggery, kidnapping and many more.

Chiganta (2009) observed that most unemployed youth survive by engaging in various activities such as petty trading, borrowing, stealing, casual work, prostitution, pick pocketing and other illegal activities. Some depend on drugs such as cocaine and Indian hemp and others have become drunkards as a result of frustration of being unemployed. Unemployment has been seen as one of the serious impediments to economic growth and progress. Unemployment is associated with street youth and area boys which encourages criminal activities and behaviours. It presents waste and loss in terms of lower output leading to lower income and poor well-being of the youths (Chiganta, 2002).

Rural-urban migration is exacerbating crime in that most youth who migrate find it difficult to cope with the demands of city life. Most of the job seekers do not have any additional skills to be selfreliant. Thus to ensure their survival, they most often involved in all manner of activities detrimental to both their life and that of the general public (Akintude, 2001; Ugal, Nwagbara \& Uyang, 2011). 


\section{THEORETICAL FRAMEWORK}

\subsection{Structural Strain Theory}

Robert Merton developed the structural strain theory as an extension of functionalism. Deviance is traced to tensions caused by the gap between cultural goals and the means people have available to achieve the goals (Andersen and Taylor, 2009). Societies are characterized by both culture and social structure. Culture sets goals while social structures designs ways to attain goals. In a well-integrated society, people adopt accepted and appropriate strategies to attain societal goals. Here, the goals and means of the society are in balance. When both goals and means are not balanced, deviance occurs. This imbalance between cultural goals and structurally available means lead individual into crime.

In Nigeria, economic success is a goal that everybody strives for. The legitimate means to economic success are education and jobs. The youth and other socially disadvantaged groups do not have equal access to these means because of their socio economic status. The result is structural strain that produces crime. They experience these strains because they aim for the same goals as the rest of society, but their opportunities for success are blocked due to poverty and unemployment. Thus, they turn to crime and deviance as a way to achieve economic success.

\subsection{Study Area}

Calabar the capital of Cross River State geographically lies between latitude $4^{0} 58^{\prime}$ North and longitude $8^{0} 17^{\prime}$ "East. The city lies on a peninsula between Calabar River and Great Kwa River, 35 miles up the Calabar River, on the nearest buildable land to the sea. Calabar Metropolis is divided into Calabar Municipality and Calabar South Local Government Areas. Calabar has three principal kingdoms namely: the Qua Kingdom, the Efut and the Efik Kingdoms. As the capital city of Cross River State, it is the seat of government of Cross River State.

Calabar has a total population of 375,196 made of 187,676 males and 187,520 females. There is an influx of immigrants to Calabar because of the economic and social potentials of the area. For instance, there is the presence of the Premier Export Processing Zone (EPZ), Tinapa Business Resort and a host of others. Most of them are either non-functioning or are gradually dying as a result of lack of managerial efficiency and absence of political will by the present state government to nurture and sustain them. Economic activities are not vibrant as should be and some ventures seem to have gone to "sleep" with the political leadership.

There is influx of youth immigrants to Calabar yearly searching for non existing employment opportunity leading to high rate of unemployment level resulting to increase in poverty among the youths. In the absence of any meaningful job to sustain them, most of them often settle for many obnoxious trades and crimes such as child trafficking, prostitution, armed robbery, theft, burglary, youth restiveness etc, some of them are hired as assassins by those in power for political reasons.

\section{Methodology}

Data for the study was collected through the use of structured questionnaire. The selection of the sample was done through simple random sampling. To ensure randomization, balloting method was employed to select ten (10) areas in Calabar Metropolis. In this method, the names of various areas in Calabar Metropolis were written in a ballot paper. Ten respondents were systematically selected from each area which formed the total of one hundred (100) respondents for the study.

\section{RESULTS}

\subsection{Hypothesis One}

There is no significant relationship between poverty and youth involvement in criminal activities. Pearson Product Moment Correlation Coefficient (rxy) was employed to explore the relationship between two variables measured continuously (see table 1).

From table 1, the calculated r-value of 0.433 was found to be higher than the critical r-value of 0.197 tested at 0.05 alpha level of significance with 98 degrees of freedom. From this significant r-value, the null hypothesis was rejected. This meant that poverty has a significant relationship with youth's involvement in criminal activities. 
Uyang, Francis Abul et al.

Table1. Pearson Product Moment Analysis Of The Relationship Between Poverty And Youth's Involvement In Criminal Activities $(N=100)$

\begin{tabular}{|c|c|c|c|c|}
\hline Variables & $\boldsymbol{\Sigma Y}$ & $\boldsymbol{\Sigma Y}^{2}$ & & \\
\hline & & & $\mathbf{\Sigma X y}$ & r-cal \\
\hline & $\boldsymbol{\Sigma x}$ & $\mathbf{\Sigma X}^{2}$ & & \\
\hline Poverty & 1532 & 2029 & & \\
\hline Youth involvement in criminal activities & 989 & 1288 & & $0.433^{*}$ \\
\hline
\end{tabular}

$*$ Correlation significant at $.05, d f=98$, critical $r=.197$

\subsection{Hypothesis Two}

There is no significant relationship between unemployment and youth involvement in criminal activities. Pearson Product Moment Correlation Coefficient (rxy) was employed to explore the relationship between two variables measured continuously (see table 1).

Table2. Pearson Product Moment Analysis of the relationship between unemployment and youth's involvement in criminal activities $(N=100)$

\begin{tabular}{|c|c|c|c|c|}
\hline Variables & $\mathbf{\Sigma Y}$ & $\mathbf{\Sigma \mathbf { Y } ^ { 2 }}$ & & $\mathbf{\Sigma}$ \\
\hline & & & $\mathbf{\Sigma X y}$ & r-cal \\
\hline Unemployment & 1289 & 1869 & & $0.594^{\mathbf{2}}$ \\
\hline $\begin{array}{c}\text { Youth involvement in } \\
\text { criminal activities }\end{array}$ & 989 & 1288 & & \\
\hline
\end{tabular}

$*$ Correlation significant at $.05, d f=98$, critical $r=.197$

From table 2, the calculated r-value of 0.594 was found to be higher than the critical r-value of 0.197 tested at 0.05 alpha level of significance with 98 degrees of freedom. From this significant r-value, the null hypothesis was rejected. This meant that unemployment has a significant relationship with youth involvement in criminal activities.

\section{DISCUSSION}

The overall findings showed that socio-economic status of youth variables (poverty and unemployment) are significant causes of youth involvement in criminal activities. The findings support Salor (2010), that the poor and the jobless in Nigeria take to crime as means of sustenance. He argued that the unemployed in Nigeria experience low self esteem, deprivation, frustration and acute want. The findings also support Benson (2004) and James (2001), that one of the reasons why youths engage themselves in criminal activities in our society is that most youths who do not have enough money to train themselves in school come from very poor home. They earn their living in the street through obnoxious criminal means deem necessary to sustain their living.

The findings resonate with Chiganta (2012) who observed that most unemployed youth survive by engaging in various activities such as stealing, prostitution, pick pocketing and other illegal activities. Collaborating Chiganta (2002) observation, Akintude (2001), Ugal, Nwagbara \& Uyang (2011) believe that most of the unemployed youths are involved in all manner of criminal activities for the sake of survival which are detrimental to both their life and that of their general public.

\section{CONCLUSION AND RECOMMENDATIONS}

Youth involvement in criminal activities as a result of their socio-economic status (poverty and unemployment) is on the increase in Nigeria in general and Calabar Metropolis in particular. In Calabar Metropolis, some youth caught in criminal activities like armed robbery, burglary and stealing evoke condemnation of societal members as such acts are punished. The youths involved in crime are social derelicts attracted into it by the socio economic status deterrent to others.

Based on the findings, the following recommendations are made:

- Parent(s) should support their children to choose vocational skills training. Investment in vocational skills acquisition could increase economic competitiveness and reduce poverty, thus, increasing productivity and employability. 
- Poverty alleviation programmes should be pro poor and well targeted, both in the rural and urban areas rather than politicians using the programme(s) to enrich themselves and compensating their supports and patronage.

- In tackling the high level of unemployment in Nigeria, both the federal government and wealthy individual should build industries in the country. This will go a long way in creating jobs for the youths and further reduce crimes among them.

- Development programmes and projects should be concentrated also in the rural areas in other to curb the problem of rural/urban drift which had increase the rate of unemployment.

\section{REFERENCES}

[1] Adebayo, A. A. (2013). Youths' unemployment and crime in Nigeria: A nexus and implications for national development, International Journal of Sociology and Anthropoloty, 5 (8), 350 - 357.

[2] Akintunde, O. (2001). Youth unemployment. Ibadan: London Press.

[3] Amadu, H. (2007). Youths and the society. Ibadan: Longman Press.

[4] Andersen, M. L. \& Taylor, H. F. (2009). Sociology, the essentials. Belmont, C.A: Thomson Wadsworth.

[5] Bassey, A. (2001). Bureaucracy and national development. Calabar: Calabar Executive Press.

[6] Benson, J. (2004). The future of Nigeria. Ile-Ife: University of Ife Press.

[7] Chambers, A. (1995). Poverty and livelihoods: whose reality realy counts? A paper commission by UNDP for World Summit for Social Development (March).

[8] Chiganta, O. (2002). Poverty: its remedies. Ibadan: Crossy Publishers.

[9] Eli, U. (2002). Crimes in Nigeria: the way forward. Lagos: Ushie Publishers.

[10] Eyegbeleye, A. (2005). Investment-led poverty reduction employment (IPRE) initiative in Obasanjo's Nigeria. Calabar: Jerry Commercial Productions.

[11] http://www.crossriverstate.gov.ng

[12] James, O. (2001). Financing local government: increasing responsibility versus inadequate resources. Enugu: Fourth Dimension Publishing.

[13] Konch, K. \& Borbora, J. (2003). Involvement of youth attitudes in crime: a study conducted in four jails of Upper Assam, India. American International Journal of Research in Humanities, Arts and Social Sciences, 2 (2), 166-121.

[14] Obandan, B. (2001). Socio-economic problems in Nigeria. Zaria: ABU publishers.

[15] Sancho, A. (1996). International encyclopedia of social science, Vol. 7 and 8. New York: Macmillan.

[16] Ugal, G. A; Nwagbara, E. N; \& Uyang, F. A. (2011). Youth unemployment and its consequences in Calabar Metropolis: need for government intervention. Global Journal of Social Sciences, 1 \& 2 (10), $75-82$.

[17] Ushie, A. (2000). Crime and it effect on Nigerian society. Jos: Chartong Publishers. 